\title{
EWOLUCJA BADAŃ NAD ZRÓWNOWAŻENIEM FINANSÓW PUBLICZNYCH
}

\section{Wprowadzenie}

Od 1980 r. w większości gospodarek rozwiniętych (i nie tylko) obserwujemy trend wzrostowy relacji długu publicznego do PKB, co według Blancharda i innych ${ }^{1}$ wynika $\mathrm{w}$ znacznym stopniu $\mathrm{z}$ rozbudowy programów zabezpieczenia socjalnego i niekorzystnych trendów demograficznych, których skutkiem są wyższe wydatki na emerytury i opiekę medyczną. Nieproporcjonalnie duża część tego długu została zakumulowana w następstwie wybuchu w 2008 r. światowego kryzysu gospodarczego, który spowodował, że w wielu krajach wartość długu publicznego przekroczyła wartość PKB. Według danych MFW² w latach 2008-2014 średnia relacja wartości długu publicznego do PKB wzrosła w krajach wysoko rozwiniętych (G20) z 85,7\% do $112,5 \%$, w tym w USA z 73,6\% do $105,1 \%$, w strefie euro z $68,6 \%$ do $91,9 \%$. W wielu krajach wzrost wartości powyższego wskaźnika był wielokrotnie większy - dla przykładu w Grecji z 109,4\% do 180,9\%, w Irlandii z 42,4\% do 104,7\%, a w Portugalii z 71,7\% do 130,6\%. Najbardziej zadłużonym państwem świata jest Japonia, której dług publiczny wyniósł w 2014 r. 242,1\% PKB i dalej szybko rośnie z powodu utrzymywania wysokiego deficytu budżetowego ${ }^{3}$. Przedstawione dane wzbudzają niepokój wśród ekonomistów i prowokują pytania, czy aby finanse publiczne w wielu krajach nie zmierzają ku katastrofie. Aby odpowiedzieć na to pytanie, należy sprecyzować kryteria oceny stabilności finansów publicznych.

Zrównoważenie finansów publicznych ma fundamentalne znaczenie dla zrównoważonego rozwoju gospodarki jako całości. Nie będzie przesadą stwierdzenie,

\footnotetext{
* Kolegium Zarządzania i Finansów, Szkoła Główna Handlowa w Warszawie.

1 O.J. Blanchard, J.-C. Chouraqui, R.P. Hagemann, N. Sartor, The sustainability of fiscal policy: New answers to an old question, „OECD Economic Studies” No. 15, Autumn 1990.

2 Międzynarodowy Fundusz Walutowy, Fiscal Monitor, październik 2017, s. 83 [dostęp 7.03.2018].

3 R. Jones, S. Urasawa, Restoring Japan's Fiscal Sustainability, „OECD Economic Department Working Paper” No. 1050, 2013.
} 
że stabilność finansów publicznych jest conditio sine qua non długofalowego rozwoju ekonomicznego państwa. Dowodów na poparcie tej tezy dostarczył chociażby niedawny kryzys zadłużenia publicznego w tzw. krajach peryferyjnych strefy euro. Zagadnienie zrównoważenia finansów publicznych jest na tyle doniosłe, że jest przedmiotem badań ekonomistów od bardzo dawna. Problem ten był podnoszony już przez merkantylistów i ekonomistów klasycznych, ale określenie formalnych warunków, jakie spełniać musi zrównoważona polityka fiskalna, zajęło ekonomistom prawie dwa stulecia. Celem artykułu jest przedstawienie ewolucji badań teoretycznych nad problemem zrównoważenia (stabilności) finansów publicznych. Metodą badawczą wykorzystaną $\mathrm{w}$ niniejszej pracy są pogłębione studia literaturowe, przy czym cytowana literatura obejmuje zarówno prace czysto teoretyczne, jak i badania stosowane nakierowane na analizę zrównoważenia finansów publicznych dla celów polityki gospodarczej. Główny nacisk położony został na badania, które ukazały się po opublikowaniu przez Domara w 1944 r. przełomowego artykułu, w którym autor przedstawił formalne warunki zrównoważenia finansów publicznych, ale opisano również badania poprzedzające publikację tej przełomowej pracy.

\section{Wczesne badania nad zrównoważeniem finansów publicznych}

Problem długu państwowego rozważali już merkantyliści, którzy wyznawali pogląd, że jego istnienie nie ma istotnego wpływu na gospodarkę tak długo, jak jest on zaciągany wewnątrz kraju. Spłatę długu krajowego i odsetek od niego porównywali oni do przekładania pieniędzy z lewej do prawej ręki. Pogląd ten został odrzucony przez Adama Smitha, który wskazywał, że akumulacja długu publicznego powoduje redystrybucję dochodu od właścicieli ziemi i kapitału do właścicieli obligacji, a przez to wpływa negatywnie na akumulację kapitału ${ }^{4}$. Ekonomiści klasyczni obawiali się również, że akumulacja długu może prowadzić do bankructwa państwa. Jak zauważają Balassone i Franco ${ }^{5}$, David Hume prezentował pogląd, że utrzymywanie permanentnego deficytu budżetowego musi prowadzić do wzrostu podatków w przyszłości albo do ogłoszenia upadłości przez państwo. Adam Smith również argumentował, że finansowanie wydatków publicznych długiem w długim okresie

\footnotetext{
4 A. Smith, An inquiry into the nature and causes of the wealth of nations, The Modern Library, New York 1994 (1776), s. 1002-1006.

5 F. Balassone, D. Franco, Assessing Fiscal Sustainability: A Review of Methods with a View to EMU, „Fiscal Sustainability Conference" Vol. 66, 2000, s. 21-60.
} 
nieuchronnie prowadzi do niewypłacalności. Większość ekonomistów klasycznych wyznawała pogląd, że deficyt budżetowy powinien być dopuszczalny tylko w przypadku nadzwyczajnych okoliczności, takich jak wojny i kataklizmy, chociaż i w tych przypadkach niektórzy z nich byli temu przeciwni.

Na wczesnym etapie rozważań nad problematyką długu publicznego w centrum zainteresowania ekonomistów znajdował się wpływ sposobu finansowania wydatków rządowych (podatki versus deficyt budżetowy) na gospodarkę realną. Toczył się wtedy spór o prawdziwość hipotezy neutralności długu publicznego, nazywanej również „ekwiwalencją ricardiańską". Zgodnie z tą hipotezą rozkład opodatkowania w czasie nie ma wpływu na gospodarkę realną. Gospodarstwa domowe, dążąc do maksymalizacji użyteczności z konsumpcji, w każdym momencie decydują, jaką część dochodu zaoszczędzić, a jaką skonsumować. Jeżeli zoptymalizowały one swoje decyzje w tym zakresie, to polityka budżetowa polegająca na obniżeniu dzisiejszych podatków kosztem wzrostu deficytu nie może mieć żadnego wpływu na gospodarkę. Jest tak dlatego, że gospodarstwa domowe, będąc świadome ograniczenia budżetowego rządu, przewidzą przyszłą podwyżkę podatków i zwiększą bieżące oszczędności dokładnie o wartość deficytu budżetowego. Od momentu jej sformułowania ekwiwalencja ricardiańska była przedmiotem ożywionego sporu, którego znakomitego opisu dostarcza Barro ${ }^{6}$.

David Ricardo uważał, że koszt finansowania długu publicznego ponoszony jest jedynie w momencie zużywania zakupionych za niego zasobów. Według Ricarda jedynym kanałem, poprzez który dług może negatywnie wpłynąć na dobrobyt kolejnych pokoleń, jest zmniejszenie akumulacji kapitału produkcyjnego. W latach 40. XX w. myśl Ricarda została rozwinięta przez zwolenników tzw. szkoły realnych zasobów, którzy uważali, że koszt finansowania długu ponoszony jest tylko przez pokolenie, za którego życia został zaciągnięty, ponieważ ponosi ono koszt alternatywny użycia kupionych za niego zasobów. Zgodnie z poglądami reprezentantów tej szkoły przyszłe pokolenia nie ponoszą kosztów obsługi długu tak długo, jak długo znajduje się on tylko w posiadaniu rezydentów. Jest tak dlatego, że społeczeństwo jako całość posiada swój własny dług, przez co odsetki są jedynie transferem między podatnikami a posiadaczami obligacji .

Wyznawcy doktryny ortodoksyjnej argumentowali, że regularne, powtarzalne wydatki państwa powinny być pokrywane z bieżących dochodów podatkowych.

6 R.J. Barro, Are Government Bonds Net Wealth?, „Journal of Political Economy” 82, No. 6, 1974, s. 1095-1117; R.J. Barro, The Ricardian Approach to Budget Deficits, „NBER Working Paper” No. 2685, 1989; R.J. Barro, Reflections on Ricardian equivalence, „NBER Working Paper” No. 5502, 1996.

7 A.P. Lerner, Functional Finance and the Federal Debt, „Social Research” Vol. 10, No. 1, 1943, s. 38-51; S. Chase, Where's the Money Coming From?, Twentieth Century Fund, New York 1943. 
Zdaniem A.C. Pigou dopuszczalne jest wykorzystanie deficytów budżetowych w celu wyrównywania wysokości podatków w czasie, ale autor zaznaczał, że deficytom w latach gorszych powinny towarzyszyć równoważące je nadwyżki budżetowe w latach lepszych, tak aby nie doszło do akumulacji długu publicznego. Pigou za uzasadnione uważał również zaciąganie długu w celu finansowania inwestycji państwowych w infrastrukturę generującą dochody, z których ten dług można spłacić. Nie zgadzał się natomiast z poglądem, że pożądane jest finansowanie długiem nadzwyczajnych wydatków związanych z wojnami i kataklizmami. Pigou argumentował, że w celu bardziej sprawiedliwej redystrybucji dochodu narodowego pożądane jest finansowanie wydatków na bieżąco poprzez nałożenie wyższych podatków na bogatych (progresja podatkowa). Ważną przyczyną sprzeciwu Pigou wobec akumulacji długu przez rząd była obawa o wzrost podaży kredytu bankowego i związany z tym wzrost inflacji ${ }^{8}$.

Istotną zmianę podejścia do długu publicznego przyniósł rozwój szkoły keynesowskiej. Wyznawcy doktryny keynesowskiej głosili, że rynek nie jest w stanie zapewnić pełnego wykorzystania mocy produkcyjnych, co uzasadnia zaciąganie przez rząd długu w celu zwiększenia zagregowanego popytu i osiągnięcia pełnego zatrudnienia. Rosnące poparcie dla interwencji państwa w gospodarce, w szczególności poprzez inwestycje publiczne, zaowocowało propozycjami wprowadzenia tzw. dualnych budżetów. Zgodnie z tą ideą wydatki inwestycyjne państwa miały zostać oddzielone od budżetu operacyjnego i być finansowane długiem publicznym. Uzasadnieniem dla takiego działania było rozłożenie kosztu finansowania zakupu dóbr inwestycyjnych na okres ich użytkowania, a także podkreślenie wpływu operacji budżetowych na majątek sektora publicznego. Dualny budżet został wprowadzony m.in. w Szwecji w 1937 r. ${ }^{9}$

Finansowanie wydatków budżetowych w oparciu o zaciąganie długu było jednak poddawane krytyce. Najważniejszym argumentem przeciwników tej polityki była konieczność podnoszenia podatków w celu późniejszej spłaty długu wraz z odsetkami. Ich zdaniem trwałe utrzymywanie dodatniego deficytu wymuszałoby podnoszenie obciążeń podatkowych aż do 100\% dochodu narodowego, a alternatywą mogłoby być tylko wyparcie się spłaty zadłużenia przez rząd albo monetyzacja długu. Keynesiści odpierali ten zarzut, argumentując, że dług wcale nie musi być spłacany, ale może być rolowany, a rosnące nominalne koszty obsługi długu w warunkach rosnącego PKB wcale nie muszą powodować wzrostu stawek podatkowych.

8 A.C. Pigou, A Study in Public Finance, MacMillan and Co. Ltd, London 1929, s. 233-251.

9 F. Balassone, D. Franco, op.cit. 
Konieczne wydaje się również odniesienie do dorobku szkoły wyboru publicznego. Jej najwybitniejszy przedstawiciel, J. Buchanan, wiele miejsca w swoich badaniach poświęcił analizie wpływu instytucji demokratycznych na kształtowanie polityki fiskalnej. Buchanan wskazywał, że społeczeństwo demokratyczne ma naturalną skłonność do zaciągania nadmiernego długu publicznego, czego przyczyną jest występowanie tzw. iluzji fiskalnej. Iluzja ta polega na tym, że wyborcy mają mylny osąd, jeżeli chodzi o korzyści i koszty programów publicznych, tzn. mają skłonność do zawyżania ich społecznej wartości i niedoszacowywania ich kosztów ${ }^{10}$. Buchanan wskazywał, że możliwość finansowania wydatków długiem rozrywa bezpośredni związek między wydatkami i podatkami, co powoduje u wyborców większą skłonność do akceptowania dodatkowych wydatków i mniejszą skłonność do akceptowania dodatkowych podatków ${ }^{11}$.

\section{Formalne kryteria zrównoważenia finansów publicznych}

Pierwszym ekonomistą, który podjął się wyprowadzenia formalnych warunków zrównoważenia polityki fiskalnej, był Domar ${ }^{12}$. Zdefiniował on zrównoważoną politykę fiskalną jako taką, w której stawka podatkowa konieczna do sfinansowania wydatków rządu (wraz z kosztami obsługi długu) zbiega do skończonej wartości. Autor ten wykazał, że przy deficycie budżetowym stanowiącym stałą część PKB, stałej i dodatniej stopie wzrostu PKB, stałych cenach i stałym oprocentowaniu długu rządowego relacja długu do PKB oraz wysokość stopy podatkowej potrzebnej do sfinansowania zobowiązań rządu zbiegają do stałych wartości:

$$
\begin{gathered}
\lim _{t \rightarrow \infty} d_{t}=b \frac{1+y}{y} \\
\lim _{t \rightarrow \infty} \tau_{t}=\lim _{t \rightarrow \infty} i \frac{d_{t-1}}{1+y}=b \frac{i}{y}
\end{gathered}
$$

gdzie: $d$ - relacja wartości długu publicznego do PKB,

$y$ - stopa nominalnego wzrostu gospodarczego,

10 J.M. Buchanan, Public Finance in Democratic Process, [w:] The Collected Works of James M. Buchanan, The University of North Carolina Press, Chapel Hill 1967, s. 125-142.

11 Ibidem, s. 97-111.

12 E.D. Domar, The "burden of the debt" and the national income, "The American Economic Review" Vol. 34, No. 4, 1944, s. 798-827. 
$b$ - relacja wartości deficytu budżetowego do PKB,

$i$ - nominalne oprocentowanie długu rządowego,

$\tau$ - stopa podatkowa.

Artykuł Domara okazał się być kamieniem milowym, jeśli chodzi o analizę zrównoważenia polityki budżetowej. Autor podkreśla znaczenie wzrostu gospodarczego dla zrównoważenia polityki fiskalnej - wykazuje, że w warunkach zerowego wzrostu gospodarczego albo wzrostu dochodu narodowego o stałe wartości absolutne trwałe utrzymywanie deficytu budżetowego musi skutkować koniecznością ciągłego podnoszenia podatków, co czyni taką politykę niezrównoważoną. Jednak w przypadku utrzymywania się dodatniej i stabilnej długookresowej stopy wzrostu gospodarczego permanentnie dodatni deficyt wcale nie musi wymuszać podwyżek podatków.

Problem zrównoważenia polityki fiskalnej odżył na nowo w latach 80 . za sprawą perspektywy rosnących wydatków rządowych związanych z niekorzystnymi trendami demograficznymi. Wprowadzanie nowych programów wsparcia socjalnego, w połączeniu ze starzeniem się społeczeństwa, skierowało uwagę ekonomistów na tzw. dług niejawny, wynikający przede wszystkim z zobowiązań systemu emerytalnego. Szacunki pokazują, że w większości krajów rozwiniętych wielkość długu niejawnego stanowi bardzo poważne wyzwanie dla stabilności finansów publicznych ${ }^{13}$. Z tego powodu ocena zrównoważenia polityki fiskalnej w oparciu o kryteria zaproponowane przez Domara przestała być wystarczająca - konieczne stało się wzięcie pod uwagę tego, jak polityka prowadzona lub implementowana dzisiaj (np. polityka emerytalna) wpływa na przyszłą ścieżkę wydatków publicznych. Problemem tym zajęli się m.in. Buiter ${ }^{14}$, Blanchard ${ }^{15}$ oraz Blanchard i inni ${ }^{16}$.

Analiza zapoczątkowana przez Domara została znacząco pogłębiona przez Buitera, który wziął pod uwagę znacznie więcej elementów niż Domar. Buiter przyjął następujące chwilowe (natychmiastowe) ograniczenie budżetowe rządu:

$$
\frac{\dot{M}+B^{S}+P^{L} \dot{B}^{L}-P_{N} \dot{N}^{G}}{P} \equiv c^{G}+\delta K^{G}+\dot{K}^{G}+\frac{i^{S} B^{S}+c B^{L}}{P}-T-\rho^{K} K^{G}-\rho^{N} N^{G}
$$

Lewa strona równania pokazuje potencjalne źródła finansowania deficytu budżetowego:

13 European Commission, The 2012 Ageing Report: Economic and budgetary projections for the EU27 Member States (2010-2060), „European Economy” 2, 2012.

14 W.H. Buiter, A guide to public sector debt and deficits, „Economic Policy” Vol. 1, Issue 1, 1985, s. $13-61$.

15 O.J. Blanchard, Suggestions for a new set of fiscal indicators, „OECD Department of Economics and Statistics Working Paper” No. 79, 1990.

16 O.J. Blanchard, J.-C. Chouraqui, R.P. Hagemann, N. Sartor, op.cit. 
(1) $\dot{M}$ - natychmiastowy przyrost podaży pieniądza (autor dopuszcza możliwość finansowania deficytu dochodami $z$ renty menniczej),

(2) $B^{S}$ - przychody z emisji krótkookresowych papierów dłużnych,

(3) $P^{L} \dot{B}^{L}$ - przychody z emisji długookresowych papierów dłużnych,

(4) $P_{N} \dot{N}^{G}$ - przychody ze sprzedaży praw własności zasobów naturalnych, które mogą być zbyte po cenie $P_{N}$.

Warto zauważyć dwie rzeczy. Po pierwsze, cena długookresowych obligacji może

się zmieniać: $P^{L}=\frac{C}{i^{S}}$, gdzie $C$ oznacza wartość kuponu, a $i^{S}$ krótkookresową stopę procentową (stałą w czasie). $P_{N} \dot{N}^{G}$ wchodzi do powyższego równania ze znakiem ujemnym, co oznacza, że sprzedaż będących w posiadaniu rządu zasobów naturalnych $\left(\dot{N}^{G}<0\right)$ pozwala na pokrycie części deficytu budżetowego.

Po prawej stronie równania znajdują się wydatki i dochody budżetu państwa. Wydatki rządowe, $G$, zostały rozbite na cztery kategorie:

(1) $c^{G}$ - wydatki na zakup dóbr konsumpcyjnych,

(2) $\delta K^{G}$ - deprecjacja kapitału będącego w posiadaniu państwa (równoważnie: koszty inwestycji odtworzeniowych),

(3) $\dot{K}^{G}$ - inwestycje kapitałowe netto (powiększające zasób kapitału będący w posiadaniu państwa),

(4) $\frac{i^{S} B^{S}+c B^{L}}{P}-$ realne koszty obsługi długu publicznego, w rozbiciu na dług krótkookresowy $\left(i^{S} B^{S}\right)$ oraz długookresowy $\left(c B^{L}\right)$.

$\mathrm{W}$ dalszej kolejności po prawej stronie znajdują się dochody budżetu, rozbite na następujące kategorie:

(1) $T$ - dochody podatkowe budżetu,

(2) $\rho^{K} K^{G}$ - dochody z kapitału będącego w posiadaniu rządu ( $\rho^{K}$ oznacza stopę zwrotu),

(3) $\rho^{N} N^{G}$ - dochody z posiadania praw własności do zasobów naturalnych (gdzie $\rho^{N}$ można traktować jako opłatę koncesyjną).

Dla uproszczenia autor zakłada, że gospodarka jest zamknięta. Zakładając, że stopy zwrotu ze wszystkich rodzajów aktywów zrównują się w stanie równowagi długookresowej oraz przyjmując natychmiastową stopę dyskontową $r^{S}$, otrzymujemy międzyokresowe równanie na ograniczenie budżetowe rządu w dowolnym momencie $t$, postaci: 


$$
\begin{gathered}
P V\left(c^{G}, t, r^{s}\right) \equiv P_{K}(t) K^{G}(t)+P_{N}(t) N^{G}(t)-\left(\frac{B^{S}(t)+P_{l}(t) B^{L}(t)}{P(t)}\right)+ \\
+P V\left(T, t, r^{s}\right)+P V\left(\frac{\dot{M}}{P}, t, r^{s}\right)+P V\left(\left(P_{K}-1\right) \dot{K}, t, r^{s}\right)+\Omega(t)
\end{gathered}
$$

Powyższe równanie głosi, że w każdym momencie $t$ wartość bieżąca wydatków rządowych na zakup dóbr konsumpcyjnych $\left(P V\left(c^{G}, t, r^{s}\right)\right)$ musi się równać „wartości netto" (net worth) rządu, czyli nadwyżce aktywów będących w jego posiadaniu nad jego zobowiązaniami. W równaniu tym w posiadaniu rządu są dwa rodzaje aktywów materialnych, którymi można handlować - kapitał o wartości $P_{K}(t) K^{G}(t)$ oraz zasoby naturalne o wartości $P_{N}(t) N^{G}(t)$, a także dwa rodzaje aktywów niematerialnych, którymi nie można handlować - wpływy podatkowe $\left(P V\left(T, t, r^{s}\right)\right)$ oraz dochód $\mathrm{z}$ senioratu $\left(P V\left(\frac{\dot{M}}{P}, t, r^{s}\right)\right)$. Zobowiązaniami po prawej stronie równania są papiery dłużne $B^{S}$ i $B^{L}$. Na „wartość netto” wpływa również akumulacja kapitału przez sektor publiczny. $\Omega(t)$ oznacza obecną wartość oczekiwanych końcowych materialnych zobowiązań netto rządu, która, po przyrównaniu do zera, pozwala na wyprowadzenie międzyokresowego ograniczenia budżetowego:

$$
\begin{aligned}
& \left(\frac{B^{S}(t)+P_{l}(t) B^{L}(t)}{P(t)}\right)-P_{K}(t) K^{G}(t)-P_{N}(t) N^{G}(t) \equiv \\
& \equiv P V\left[T-c^{G}+\left(P_{K}-1\right) \dot{K}, t, r^{S}\right]+P V\left(\frac{\dot{M}}{P}, t, r^{s}\right)
\end{aligned}
$$

Warunek $\Omega(t)=0$ nazywany jest warunkiem transwersalności (transversality condition) i nie pozwala rządowi zadłużać się w nieskończoność („no Ponzi game”). Powyższe równanie może również zostać wyrażone w relacji dochodu narodowego:

$$
\begin{aligned}
& \left(\frac{B^{S}(t)+P_{l}(t) B^{L}(t)}{P(t) Y(t)}\right)-P_{K}(t) \frac{K^{G}(t)}{Y(t)}-P_{N}(t) \frac{N^{G}(t)}{Y(t)} \equiv \\
\equiv & P V\left[\frac{T-c^{G}+\left(P_{K}-1\right) \dot{K}}{Y}, t, r^{S}-y\right]+P V\left(\frac{\dot{M}}{P}, t, r^{S}-y\right)
\end{aligned}
$$


Należy zwrócić uwagę na istotną zmianę w stosunku do równania powyżej, a mianowicie to, że w równaniu pojawiła się stopa wzrostu gospodarczego $y$, która weszła do niego ze znakiem ujemnym przy stopie procentowej $r^{s}$. Relacja tych dwóch wartości ma istotne implikacje dla długookresowej wypłacalności rządu. Jeżeli realna stopa procentowa byłaby trwale niższa niż stopa realnego wzrostu gospodarczego, to możliwe byłoby zadłużanie się w nieskończoność, czyli wieczne finansowanie odsetek od długu emisją nowego długu, a warunek $\Omega(t)=0$ stałby się zupełnie arbitralny. Buiter dowodzi, że w tej sytuacji rząd nie musiałby nakładać żadnych podatków, a nawet mogłyby one być trwale ujemne. Jakkolwiek sytuacja taka jest trudna do wykluczenia na gruncie teoretycznym, to dane empiryczne wskazują, że powinna być traktowana jako osobliwy wyjątek od reguły. $Z$ tego powodu Buiter zakłada, że $r^{S}>y$, a warunek transwersalności musi zostać spełniony.

Znamy już warunek równowagi dla polityki fiskalnej. Warto w tym miejscu zadać pytanie, co dzieje się w przypadku, gdy nie jest on spełniony? Oczywistą możliwością jest skorygowanie przez rząd prowadzonej polityki budżetowej poprzez cięcia wydatków albo podwyżkę podatków. Mniej oczywistą opcją jest próba zwiększenia dochodów z renty menniczej (poprzez zwiększenie stopy przyrostu podaży pieniądza, $\dot{M}$ ), ale autor dowodzi, że jeżeli taka polityka jest oczekiwana przez podmioty gospodarcze, to jest mało obiecująca ze względu na niski potencjał dochodowy. Jeżeli stopa zwrotu $\mathrm{z}$ kapitału będącego w posiadaniu rządu jest wyższa (niższa) od kosztu alternatywnego, to rząd może próbować zwiększyć (zmniejszyć) wydatki na jego akumulację. Teoretyczną opcją jest również próba zwiększenia dochodów z istniejącego zasobu kapitału będącego w posiadaniu rządu. Opcje te oczywiście wzajemnie się nie wykluczają i możliwe jest zastosowanie ich kombinacji. Możliwością rozważaną przez autora jest również próba monetyzacji długu. W odróżnieniu od zwiększenia dochodów z senioratu, które polega na trwałym podniesieniu stopy wzrostu podaży pieniądza (a tym samym trwałym podniesieniu stopy inflacji), przez monetyzację długu autor rozumie działanie powodujące jednorazowy, skokowy i, co ważne, niespodziewany wzrost średniego poziomu cen. Efekt taki w gospodarce otwartej można osiągnąć poprzez dokonanie dewaluacji waluty krajowej. Opcja ta jest jednak niemożliwa w warunkach płynnego kursu walutowego, a także jeżeli wartość długu jest indeksowana przy użyciu wskaźnika CPI albo deflatora PKB. Jeżeli rząd nie podejmie działań korekcyjnych, mających na celu przywrócenie stabilności polityki fiskalnej, to musi się wydarzyć coś, co spowoduje, że warunek transwersalności, który nie był spełniony ex ante, zostanie spełniony ex post. Czymś takim jest ogłoszenie przez rząd niewypłacalności, czyli wyparcie się spłaty całości albo części zadłużenia. 


\section{Kryteria zrównoważenia finansów publicznych dla skończonego horyzontu czasowego}

Wyprowadzony wyżej warunek stabilności polityki fiskalnej napotyka poważne przeszkody, jeżeli chodzi o jego praktyczne zastosowanie. Buiter wskazuje na problemy związane ze statystyczną klasyfikacją niektórych pozycji. Dla przykładu, wydatki na edukację i służbę zdrowia klasyfikowane są jako wydatki na dobra konsumpcyjne, podczas gdy jego zdaniem powinny być traktowane jako inwestycje w akumulację (odtworzenie) kapitału ludzkiego (wskazywał na to również Domar ${ }^{17}$ ). Kolejnym poważnym problemem jest nieskończony horyzont czasowy. Sprawdza się to w modelu teoretycznym, ale w praktyce niemożliwe jest prognozowanie wartości potrzebnych zmiennych od dzisiaj do nieskończoności, co implikuje konieczność przyjmowania arbitralnych założeń. Przypomnijmy, że do badań nad długookresową stabilnością polityki fiskalnej ekonomistów zainspirowały rosnące wydatki budżetowe związane $\mathrm{z}$ rozrostem państwa socjalnego oraz niekorzystne trendy demograficzne. $\mathrm{W}$ tym kontekście przydatne byłyby wskaźniki, które pozwalałyby ocenić zrównoważenie polityki budżetowej oraz konsekwencje wprowadzanych programów społecznych (np. emerytalnych) w skończonym horyzoncie czasowym, powiedzmy jednego-dwóch pokoleń. Zadania tego podjęli się Blanchard i inni ${ }^{18}$. Przejdziemy teraz do analizy wyników ich pracy.

Blanchard i inni skonstruowali trzy wskaźniki służące do oceny stabilności polityki fiskalnej: krótko-, średnio- i długookresowy. Pierwszy z nich dotyczy bardzo krótkiego okresu (roku). Drugi z nich dotyczy okresu 5-letniego i ma na celu uchwycenie zmian wydatków i dochodów budżetowych w ramach cyklu koniunkturalnego. Trzeci wskaźnik służy ocenie stabilności polityki fiskalnej w bardzo długiej perspektywie (40 lat) i jego celem jest uwzględnienie konsekwencji starzenia się społeczeństwa na kondycję finansów publicznych. Autorzy przyjęli nieco inną definicję zrównoważonej polityki fiskalnej niż Buiter - według nich za stabilną należy uznać politykę budżetową, która w ustalonym horyzoncie czasowym pozwala na powrót relacji długu publicznego $\left(b_{n}\right)$ do dochodu narodowego do początkowego poziomu $\left(b_{0}\right)$. Ewolucję relacji długu do dochodu narodowego opisują równania:

$$
b_{n}=b_{0} e^{(r-y) n}+\int_{0}^{n} d_{s} e^{(r-y)(n-s)} d s
$$

17 E.D. Domar, op.cit.

18 O.J. Blanchard, J.-C. Chouraqui, R.P. Hagemann, N. Sartor, op.cit. 


$$
d=g+h-t
$$

gdzie: $b$ - relacja długu publicznego do PNB,

$d$ - relacja pierwotnego deficytu budżetowego do PNB,

$g$ - relacja wydatków rządowych do PNB,

$h$ - relacja transferów do $\mathrm{PNB}$,

$t$ - stopa podatkowa (\% PNB),

$r$ - realna stopa procentowa (ex post),

$y$ - tempo wzrostu realnego PNB.

Podobnie jak Buiter, Blanchard i inni przyjmują, że $r>y$. Dyskontując wszystkie wartości na okres bieżący (mnożąc obie strony równania przez $e^{-(r-y) n}$ ) oraz licząc granicę przy $n$ dążącym do nieskończoności, otrzymujemy:

$$
\lim _{n \rightarrow \infty} b_{n} e^{-(r-y) n}=0
$$

oraz

$$
\int_{0}^{\infty} d_{s} e^{-(r-y) s} d s=-b_{0}
$$

Pierwsze z powyższych równań mówi, że jeżeli relacja długu publicznego do PNB ma w końcu powrócić do początkowego poziomu, to bieżąca wartość długu publicznego musi w nieskończoności wynosić zero. Drugie z powyższych równań mówi, że bieżąca wartość strumienia przyszłych pierwotnych deficytów budżetowych musi równać się wielkości zadłużenia w $t=0$ (równoważnie: rządy, które odziedziczyły po poprzednikach niezerowy dług publiczny, muszą prędzej czy później osiągnąć pierwotne nadwyżki w budżecie, które pozwolą na jego spłatę).

Podstawiając do ostatniego równania $d=g+h-t$ i przekształcając, otrzymujemy

$$
t^{*}=(r-y)\left[\left(\int_{0}^{\infty}(g+h) e^{-(r-y) s} d s\right)+b_{0}\right]
$$

gdzie $t^{*}$ oznacza stałą stopę podatkową, która zapewnia stabilność polityki fiskalnej. Jeżeli aktualna stopa podatkowa $t$ jest niższa niż $t^{*}$, to rząd, aby przywrócić stan długookresowej równowagi, musi ją podnieść lub dokonać dostosowań po stronie wydatkowej. Wielkość koniecznej korekty wynosi $\left(t^{*}-t\right)$. Autorzy zwracają uwagę, że jeżeli stopa podatkowa już jest wysoka, to sytuacja jest szczególnie poważna, ponieważ nie można liczyć na znaczące zwiększenie dochodów podatkowych. Dlatego proponują 
normalizację wskaźnikado postaci $\frac{\left(t^{*}-t\right)}{1-t}$, która uwzględnia, jaką część dochodu narodowego rząd może jeszcze odebrać obywatelom w formie podatków ${ }^{19}$.

Ostatecznym celem analizy jest stworzenie wskaźników dla skończonego horyzontu czasowego. Przyjmując, że liczba okresów jest równa $n$, mamy:

$$
t_{n}^{*}=(r-y)\left[b_{0}+\frac{1}{1-e^{-(r-y) n}} \int_{0}^{n}(g+h) e^{-(r-y) s} d s\right]
$$

Powyższe równanie głosi, że stopa podatkowa (stała dla przyszłych $n$ okresów) musi być wystarczająco wysoka, żeby relacja długu do PNB pozostała na niezmienionym poziomie plus zdyskontowana wartość wydatków rządu na zakup dóbr i usług i transfery w okresie od 0 do $n$, znormalizowane w taki sposób, że suma wag dla $(g+h)$ w poszczególnych okresach sumowała się do 1 .

W oparciu o powyższe warunki autorzy proponują trzy wskaźniki zrównoważenia polityki fiskalnej (krótko-, średnio- i długookresowy), pokazujące wielkość luki podatkowej $\left(t^{*}-t\right)$ :

(1) krótkookresowy (rok): $g+h-t+(r-y) b_{0}=d+(r-y) b_{0}$,

(2) średniookresowy (5 lat): [('́rednia $g+h$ dla kolejnych 5 lat $\left.)+(\mathrm{r}-\mathrm{y}) b_{0}\right]-t$,

(3) długookresowy (40 lat): jak wyżej, ale dla 40 lat.

Autorzy uzasadniają przyjęcie 5-letniego horyzontu czasowego dla wskaźnika średniookresowego kompromisem między chęcią wzięcia pod uwagę wahań cyklicznych a dostępnością wiarygodnych prognoz. Do swoich kalkulacji użyli 5-letnich prognoz realnych stóp procentowych $(r)$ i stóp realnego wzrostu gospodarczego $(y)$ publikowanych przez OECD. W przypadku wskaźnika długookresowego autorzy oszacowali skutki starzenia się społeczeństwa dla przyszłych wartości $g$ i $h$, a dokładniej prognozę wydatków na przyszłe emerytury i opiekę medyczną. Powyższe wskaźniki zainspirowały Komisję Europejską do kalkulowania podobnych (przynajmniej na początku, bo przechodziły one proces „ewolucji”) wskaźników dla krajów Unii Europejskiej ${ }^{20}$ :

\footnotetext{
19 Powyższy wskaźnik może być mylący ze względu na cząstkowy charakter zastosowanego modelu, który nie uwzględnia wpływu podniesienia stopy podatkowej na wartość dochodu narodowego i szarej strefy, a tym samym bazy podatkowej. Zwolennicy tzw. ekonomii podażowej skrytykowaliby tę postać wskaźnika, wskazując na kształt krzywej Laffera, która zakłada kwadratową, a nie liniową relację między stawką podatkową a wpływami do budżetu.

20 Dokładny opis konstrukcji wyżej wymienionych wskaźników można znaleźć w: European Commission, Fiscal Sustainability Report 2015, „Institutional Papers” 18, Brussels, January 2016.
} 
- wskaźnika wczesnego wykrywania ryzyka napięcia fiskalnego (ang. early-detection indicator of fiscal stress risk) oznaczanego skrótem „SO”,

- wskaźnika oceny zrównoważenia średniookresowego (ang. medium-term sustainability indicator) oznaczanego skrótem "S1",

- wskaźnika oceny zrównoważenia długookresowego (ang. long-term sustainability indicator) oznaczanego skrótem „S2”.

Jakkolwiek wkład Domara, Buitera i Blancharda i innych w prace nad zagadnieniem zrównoważenia polityki fiskalnej jest bardzo istotny, to pod adresem wyprowadzonych przez nich równań kierowane są poważne zarzuty, które w większości wiążą się z naturą zastosowanego modelu (równowagi cząstkowej). Po pierwsze, autorzy ograniczali się dotąd do analizy gospodarki zamkniętej. Po drugie, za każdym razem przyjmowali, że oprocentowanie długu rządowego jest egzogeniczne, a może ono przecież zależeć chociażby od oceny wiarygodności rządu przez inwestorów (premia za ryzyko) czy interakcji między polityką fiskalna a polityką pieniężną. Po trzecie, ich modele nie biorą pod uwagę wpływu stopy podatkowej na gospodarkę, a tym samym na bazę podatkową. Krytycy argumentują, że wysokie podatki mogą negatywnie wpłynąć na tempo wzrostu gospodarczego lub spowodować ucieczkę do szarej strefy, ograniczając zdolność rządu do uzyskiwania dochodów budżetowych, koniecznych do sfinansowania zaciągniętych zobowiązań. Jak dotąd nikt nie wyprowadził warunków zrównoważenia polityki fiskalnej przy użyciu narzędzi równowagi ogólnej. Zapełnienie tej luki będzie jednak bardzo trudne ze względu na ogromną złożoność analizowanego problemu.

Krytyka wyprowadzonych wyżej warunków stabilności polityki fiskalnej nie ogranicza się do argumentów przytoczonych w poprzednim paragrafie. Collignon ${ }^{21}$ uważa, że błędem jest ograniczanie się wyłącznie do analizy międzyokresowego ograniczenia budżetowego. Jest tak dlatego, że chociaż jego spełnienie jest warunkiem koniecznym długookresowej wypłacalności, to według tego autora nie jest warunkiem wystarczającym. Collignon argumentuje, że rząd może być wypłacalny w tym sensie, że jest w stanie obsłużyć swoje zadłużenie z przyszłych wpływów podatkowych, ale może utracić płynność, jeżeli nie jest w stanie zrolować starego długu po umiarkowanej stopie procentowej. Taki kryzys płynności może prowadzić do gwałtownego wzrostu kosztów obsługi długu i w konsekwencji do kryzysu wypłacalności, jak miało to miejsce w przypadku Grecji. Autor argumentuje, że nikt dotąd nie wykazał, że grecki dług publiczny był niemożliwy do obsłużenia w długim okresie, a mimo

21 S. Collignon, Fiscal policy rules and the sustainability of public debt in Europe, „International Economic Review" 53, No. 2, 2012, s. 539-567. 
wszystko rynek utracił zaufanie do greckiego rządu, czego skutkiem był kryzys płynności, który przerodził się w kryzys wypłacalności.

\section{Podsumowanie}

Zrównoważenie finansów publicznych jest zagadnieniem fundamentalnie ważnym dla stabilności makroekonomicznej i zrównoważonego wzrostu gospodarczego. Problem ten był badany przez ekonomistów od około dwóch wieków, a do najważniejszych wyników tych badań należy wyprowadzenie przez Domara w 1994 r. formalnych warunków zrównoważenia finansów publicznych, które zostały rozwinięte przez Buitera, Blancharda i innych, i obecnie są powszechnie stosowane przez instytucje takie jak Komisja Europejska czy Międzynarodowy Fundusz Walutowy ${ }^{22}$ do oceny zrównoważenia polityki fiskalnej. Warunki te są krytykowane za przyjmowanie stopy oprocentowania długu publicznego jako egzogenicznej, a także ograniczanie się do analizy gospodarki zamkniętej. Co więcej, Collignon uważa, że warunki te określają tylko warunki konieczne, a nie wystarczające, a rząd może stać się niewypłacalny nawet przy ich spełnieniu, jeżeli nie jest w stanie zrolować długu po umiarkowanej stopie procentowej. Wzrost zadłużenia publicznego zwiększył zainteresowanie ekonomistów tym tematem i należy się spodziewać nowych publikacji naukowych dotyczących tego zagadnienia. Największym wyzwaniem dla ekonomistów pozostaje nadal sformułowanie warunków zrównoważenia polityki fiskalnej w gospodarce otwartej i przy endogenicznej stopie oprocentowania długu publicznego. Sprostanie temu wyzwaniu będzie jednak bardzo trudne, co wynika z ogromnej złożoności tego problemu badawczego.

\section{Literatura}

Balassone F., Franco D., Assessing Fiscal Sustainability: A Review of Methods with a View to EMU, „Fiscal Sustainability Conference” Vol. 66, 2000, s. 21-60, https://papers.ssrn. com/sol3/papers.cfm?abstract_id=2109377

22 E. Tanner, Fiscal Sustainability: A 21st Century Guide for the Perplexed, „IMF Working Paper” No. 13/89, 2013; J. Escolano, A Practical Guide to Public Debt Dynamics, Fiscal Sustainability, and Cyclical Adjustment of Budgetary Aggregates, „IMF Technical Notes and Manuals” No. 2010/02, 2010; N.A. Chalk, R. Hemming, Assessing Fiscal Sustainability in Theory and Practice, „IMF Working Paper” No. 00/81, 2000. 
Barro R.J., Are Government Bonds Net Wealth?, „Journal of Political Economy” 82, No. 6, 1974, s. 1095-1117, https://doi.org/10.1086/260266

Barro R.J., Reflections on Ricardian equivalence, „NBER Working Paper” No. 5502, 1996, http://www.nber.org/papers/w5502.pdf?new_window=1

Barro R.J., The Ricardian Approach to Budget Deficits, „NBER Working Paper” No. 2685, 1989, http://www.nber.org/papers/w2685

Blanchard O.J., Suggestions for a new set of fiscal indicators, „OECD Department of Economics and Statistics Working Paper” No. 79, 1990, https://www.oecd.org/eco/outlook/2002735.pdf

Blanchard O., Chouraqui J.-C., Hagemann R.P., Sartor N., The sustainability of fiscal policy: New answers to an old question, „OECD Economic Studies” No. 15, Autumn 1990, http://www.oecd.org/eco/outlook/34288870.pdf

Buchanan J.M., Public Finance in Democratic Process, [w:] The Collected Works of James M. Buchanan, The University of North Carolina Press, Chapel Hill 1967.

Buiter W.H., A guide to public sector debt and deficits, „Economic Policy” Vol. 1, Issue 1, November 1, 1985, s. 13-6, https://doi.org/10.2307/1344612

Chalk N.A., Hemming R., Assessing Fiscal Sustainability in Theory and Practice, „IMF Working Paper” No. 00/81, 2000, https://www.imf.org/ /media/Websites/IMF/imported-full-text-pdf/external/pubs/ft/wp/2000/_wp0081.ashx

Chase S., Where's the Money Coming From?, Twentieth Century Fund, New York 1943.

Collignon S., Fiscal policy rules and the sustainability of public debt in Europe, „International Economic Review” 53, No. 2, 2012, s. 539-567, http://onlinelibrary.wiley.com/ doi/10.1111/j.1468-2354.2012.00691.x/abstract

Domar E.D., The "burden of the debt" and the national income, „The American Economic Review" Vol. 34, No. 4, 1944, s. 798-827, http://www.jstor.org/stable/1807397

Escolano J., A Practical Guide to Public Debt Dynamics, Fiscal Sustainability, and Cyclical Adjustment of Budgetary Aggregates, „IMF Technical Notes and Manuals” No. 2010/02, 2010, https://www.imf.org/ /media/Websites/IMF/imported-full-text-pdf/external/ pubs/ft/tnm/2010/_tnm1002.ashx

European Commission, Fiscal Sustainability Report 2015, „Institutional Papers” 18, Brussels, January 2016, https://ec.europa.eu/info/sites/info/files/file_import/ip018_en_2.pdf

European Commission, The 2012 Ageing Report Economic and budgetary projections for the EU27 Member States (2010-2060), „European Economy” 2, 2012, http://ec.europa. eu/economy_finance/publications/european_economy/2012/pdf/ee-2012-2_en.pdf

Jones R., Urasawa S., Restoring Japan's Fiscal Sustainability, „OECD Economic Department Working Paper" No. 1050, 2013, http://www.oecd-ilibrary.org/economics/restoring-japan-s-fiscal-sustainability_5k46cvtkbf33-en

Lerner A.P., Functional Finance and the Federal Debt, „Social Research” Vol. 10, No. 1, 1943, s. 38-51, http://www.jstor.org/stable/40981939 
Międzynarodowy Fundusz Walutowy, Fiscal Monitor, październik 2017, http://www.imf. org/en/publications/fm/issues/2017/10/05/fiscal-monitor-october-2017

Pigou A.C., A Study in Public Finance, MacMillan and Co. Ltd, London 1929, https:// archive.org/details/in.ernet.dli.2015.499574

Smith A., An inquiry into the nature and causes of the wealth of nations, The Modern Library, New York 1994 (1776).

Tanner E., Fiscal Sustainability: A 21st Century Guide for the Perplexed, „IMF Working Paper” No. 13/89, 2013, https://www.imf.org/ /media/Websites/IMF/imported-fulltext-pdf/external/pubs/ft/wp/2013/_wp1389.ashx

\section{Evolution of Research on Sustainability of Public Finance}

From the 1980s onwards, an upward trend in the ratio of public debt to GDP has been observed in developed countries (and not only). Public debt in many countries has exceeded GDP. In Japan, the world's most indebted country, it has exceeded $250 \%$ of GDP and continues to grow rapidly. These figures raise concerns among economists and lead to questions whether public finances in these countries are sustainable. To answer those questions, the criteria for assessing the sustainability of public finance need to be specified. This problem was already investigated by classical economists, however, the definition and the formal conditions for a balanced fiscal policy were specified by economists almost two centuries later. The aim of this article is to present the evolution of theoretical research on the problem of sustainability of public finance.

Keywords: sustainability, public finance, public debt, budget deficit

\section{L'évolution de la recherche sur la durabilité des finances publiques}

À partir des années 1980, dans la majorité des pays très développés (et pas seulement) on observe une tendance à la hausse du ratio dette publique/PIB. Dans de nombreux pays la dette publique a dépassé la valeur du PIB et dans le pays le plus endetté du monde, le Japon, a dépassé $250 \%$ du PIB et continue de croître rapidement. Les données citées ci-dessus suscitent l'inquiétude des économistes et provoquent des interrogations sur la possibilité que les finances publiques de ces pays se dirigent vers une catastrophe. Pour répondre à cette question, les 
critères d'évaluation de la durabilité des finances publiques doivent être précisés. Ce problème a déjà été examiné par les économistes classiques, mais il a fallu près de deux siècles aux économistes pour déterminer les conditions formelles à remplir par une politique fiscale équilibrée. L'objectif de cet article est de présenter l'évolution de la recherche théorique sur le problème de la durabilité (stabilité) des finances publiques.

Mots-clés: durabilité, stabilité, finances publiques, dette publique, déficit budgétaire

\section{Эволюция исследований в области устойчивости государственных финансов}

Начиная с 1980-х годов, в большинстве высокоразвитых стран (и не только) наблюдается тенденция к увеличению показателя отношения государственного долга к ВВП. Во многих странах государственный долг превысил ВВП, а в самой задолженной стране мира - Японии - 250\% ВВП и продолжает быстро расти. Эти цифры вызывают у экономистов озабоченность. Возникают вопросы о том, не приведет ли это государственных финансов этих стран к катастрофе. Чтобы ответить на эти вопросы, необходимо указать критерии оценки устойчивости государственных финансов. Эта тема рассматривалась уже классическими экономистами, но потребовались почти два столетия, чтобы определить формальные условия, которые должны быть выполнены в отношении устойчивой фискальной политики. Цель этой статьи заключается в том, чтобы представить эволюцию теоретических исследований проблемы устойчивости государственных финансов.

Ключевые слова: устойчивость, государственные финансы, государственный долг, дефицит бюджета 